\title{
A támogató környezet szerepe a szülési stressz kezelésében
}

\author{
Rados Melinda ${ }^{1}$ - Mészáros Judit dr. ${ }^{2}$ \\ ${ }^{1}$ Semmelweis Egyetem, Egészségtudományi Kar, Alkalmazott Pszichológia Tanszék, Budapest \\ ${ }^{2}$ Semmelweis Egyetem, Egészségtudományi Kar, Budapest
}

\begin{abstract}
Bevezetés: A szülés érzelmi, kognitív, viselkedéses vonatkozásai, a megtapasztalt stressz szoros kapcsolatban állnak bizonyos fiziológiai háttérfolyamatokkal.

Célkitüzés: Vizsgálni kívántuk a szülés közbeni fizikai környezet biztonságának, a szüléskísérők támogatásának, a mesterséges oxitocinadagolásnak mint beavatkozásnak összefüggéseit az észlelt stressz viszonylatában.

Módszer: Kutatásunkban a nők stressz-szintjére a rövidített Észlelt Stressz Skálával, a fizikai és szociális környezet biztonságára, a mesterséges oxitocinadagolásra külön kérdésekkel kérdeztünk rá.

Eredmények: A stressz, a fizikai és szociális biztonság között szoros negatív összefüggés mutatkozott. Az átlag alatti fizikai és szociális biztonságot megtapasztalók csoportja szignifikánsan magasabb stresszt élt át; és az, aki kapott oxitocint, nagyobb stresszt és kisebb fizikai és szociális biztonságérzetet észlelt.

Következtetések: Mivel szülés során a fiziológiai és pszichés folyamatok, viselkedések szorosan hatnak egymásra, javasoljuk a beavatkozásmentes, természetes élettani szülés támogatását, ami az anya és gyermeke hosszú távú érdekeit is szolgálja. Egy modellben szemléltetjük a nyugodt fizikai környezet, a minimális beavatkozás és a szüléskísérôi támogatás hozzájárulását az anya biztonságos és kielégítő szülésélményéhez.

Orv Hetil. 2017; 158(29): 1149-1156.
\end{abstract}

Kulcsszavak: szülési stressz, fiziológiai szülés, szülészeti beavatkozás, oxitocin, emocionális támogatás

\section{The role of environmental factors in managing labour stress}

Introduction: Emotional, cognitive and behavioural aspects of birth and labour stress are strongly associated with the underlying physiological processes.

Aim: To study the factors of physical security and social support, the administration of synthetic oxytocin, and how they relate to perceived stress during childbirth.

Method: Women's experienced physical security, social support and oxytocin administration was measured with targeted questions, and their perceived stress with the short and modified version of the Perceived Stress Scale.

Results: A strong negative association was found between perceived stress and physical and social security. The group of women experiencing low physical and social security perceived significantly higher stress, while those given synthetic oxytocin perceived higher stress, and lower physical and social security.

Conclusions: Since physiological, psychological processes and behaviours are strongly intertwined, the support of natural physiological birth without interventions is recommended, which considers not only short-term but longterm health consequences for mother and child. The contribution of calming physical surroundings, minimal interventions and empowering support of caregivers to safe and satisfying birth is demonstrated in a model.

Keywords: labour stress, physiological birth, birth intervention, oxytocin, emotional support

Rados M, Mészáros J. [The role of environmental factors in managing labour stress]. Orv Hetil. 2017; 158(29): 1149-1156.

(Beérkezett: 2017. április 28.; elfogadva: 2017. június 1.)

\begin{abstract}
Rövidítések
CIPS $=($ Childbirth Intimacy and Privacy Scale $)$ Szülési Intimitás és Privát Szféra Skála; CTG $=($ cardiotocography) magzati szívhang-monitorozás; $\mathrm{EDA}=$ (epidural analgesia) epiduralis analgesia; PSS $=($ Perceived Stress Scale $)$ Észlelt Stressz Skála
\end{abstract}

A perinatalis időszak a nők számára fiziológiai, emocionális, kognitív és viselkedéses szinten különböző változásokat hoz. A megtapasztalt fiziológiai és pszichés változások bonyolult interakcióik révén hozzák létre az anyai szülési élményeket, és segítik az anya és gyermeke alkal- 
mazkodását a szülés után kialakult új helyzethez. Ezen folyamatok mögött egy olyan fiziológiai, hormonális mintázat rajzolódik ki, ami mindezen változásoknak egy egységes hátteret biztosít [1]. Ez az időszak, és azon belül a szülés mint kiemelkedő esemény, sok stresszel jár. A fizikai és a szociális környezet támogatása, a nyugalom biztosítása és csak a legszükségesebb beavatkozások végzése, mind alapvető szerepet játszanak a szülési stressz oldásában, és ezáltal a vajúdás és szülés érzékeny hormonális egyensúlyának fenntartásában. Ilyen körülmények között valódi értelmet nyer a nőközpontú szülészeti ellátás; a nő biztonságos körülmények között szülheti meg gyermekét, valamint szüléséről nemcsak rövid, hanem hosszú távon is pozitívan, elégedetten vélekedhet, stabil alapot biztosítva az anyaság új kihívásaihoz [2].

Az élet egy dinamikus egyensúlyi állapot, vagyis a homeosztázis által valósul meg, amelyet állandóan különböző stresszorok állítanak kihívás elé. Walter Cannon elmélete alapján a stressz fiziológiai szinten a szervezet homeosztázisát veszélyezteti [3]. Selye János szerint a stressz a szervezet nem specifikus reakciója minden olyan ingerre, amely kibillenti eredeti egyensúlyi állapotából és alkalmazkodásra kényszeríti. Ezenkívül hangsúlyozza, hogy a stressz nemcsak káros lehet, hanem létezik olyan pozitív stresszállapot, amely mint egy kihívás inkább ösztönzőleg hat az egyedre, egyénre [4]. Lazarus a stresszt a megzavart személy-környezet kapcsolatból eredezteti, amelyen a személy megküzdése révén képes változást előidézni [3]. Egy szerzőtársával együtt arra hívják fel a figyelmet, hogy a személy emocionális állapotait, stresszhelyzettel való megküzdését és megküzdésre használt forrásait nem statikus struktúrákként, hanem azok folyamatosan változó és bontakozó viszonyaként kell elképzelnünk [5]. Csak így vagyunk képesek megragadni, hogy a személy egy adott pillanatban valóban hogyan érez. A szülési stressz az anyáknál a vajúdás és szülés folyamán tapasztalt fájdalom és félelem miatt jelenik meg [6]. Az ilyenfajta negatív, kellemetlen stressz belső oka az erős méhösszehúzódások okozta szülési fájdalom, a saját, illetve baba jólléte miatti szorongás, az emocionális megterhelés, illetve az anya saját képességébe vetett hitének hiánya, hogy gyermekét saját testére hagyatkozva, külső beavatkozástól mentesen képes megszülni. Selyére visszautalva azonban megállapíthatjuk, hogy a szülési stressznek van pozitív oldala is, amely az izgatottsággal és a várva várt gyermek megszületése iránti vágyakozással kapcsolatos. Az előbbiekben részletezett stressz tulajdonképpen a szülés természetéből eredő endogén (belső forrásból származó) stressz.

Szülés közben számos exogén, vagyis külső stresszforrással is találkozhatunk a felmerülő anyai és magzati komplikációkon túl: az anya emocionális állapotaira nem érzékeny szüléskísérői magatartás, a rideg fizikai környezet, a privát szféra hiánya, túl sok ember jelenléte a szülőszobán, az előkészítésként végrehajtott beöntés és borotválás, infúzió bekötése, vajúdás és kitolás során végig felszerelt magzati szívhangvizsgáló (CTG) eszköz, a gya- kori vaginális vizsgálat, és természetesen minden egyes, a szülés természetes lefolyásába való külsődleges beavatkozás [7]. A beavatkozásokkal kapcsolatban meg kell jegyeznünk, hogy a baba és anya egészsége érdekében egyes beavatkozások természetesen elengedhetetlenek, de az indokolatlan használatuk felesleges stresszt és megküzdési kényszert jelent a szülőnő részére, aminek nem várt emocionális és visszacsatolások révén fiziológiai hatásai lehetnek magára a szülés lefolyására is.

Uvnäs Moberg svéd kutatónő felhívja a figyelmet arra, hogy nem elég csak molekuláris szinten vizsgálódnunk az ember fiziológiai és hormonális múködésével kapcsolatban, hanem rendszerszerú múködésüket is észre kell vennünk [1]. Így fedezte fel és vetette meg a „nyugalom és összetartozás” rendszer (calm and connection system) alapját. A korábban már ismert fizikai vagy pszichológiai stressz esetén múködésbe lépő és a szervezet rejtett energiáit mobilizáló „harcolj vagy menekülj” (fight or flight) rendszert ugyanis ki kell egészítse egy, a szervezet feltöltődéséért, megnyugvásáért, gyógyulásáért és a szociális kapcsolódásért felelős „nyugalom és összetartozás” rendszer. Ez utóbbi segít nekünk, hogy optimista és kreatív módon élvezhessük az életet, és ha kell, teljes figyelemmel, koncentrációval tanulhassunk, fejlődhessünk. Ebben a rendszerben nagy hangsúlyt kapnak az érzékszervek segítségével felfogható érzékletek, amelyek közül kiemelkedik a tapintás, a további bőrérzékletek, valamint a szaglás. A stressz esetén aktiválódó „harcolj vagy menekülj” rendszer és a „nyugalom és összetartozás” rendszer egymással egyensúlyban tartják fenn a szervezet jóllétét, vagyis együttesen biztosítják az életben maradás feltételeit.

A környezetből érkező külső stresszorok sorában meg kell említenünk a szülés helyszínéül szolgáló helyiség fizikai környezetét, amely szintén hatással van a környezetet használó szülőnőre, illetve szüléskísérőire: a barátságos, otthonos környezet az embereket megnyugtatja, és a „calm and connection” rendszer aktivitásán keresztül hozzájárul a szervezet oxitocinszintjének növeléséhez [8]. A túl rideg, ijesztő, túl sok alkalmazkodást igénylő terek, illetve a számos technikai eszköz (például infúziók, CTG, újjáélesztéshez szükséges eszközök) látványa viszont stresszkeltő, és katecholaminok kibocsátásán keresztül a szervezetet a harcra vagy a menekülésre készítik fel $[8,9]$. Ebben az esetben viszont a kívánatos „calm and connection" rendszer helyett a "fight or flight” stresszreakció játssza a karmester szerepét, ennek okán csökken az anya szervezetében az oxitocinszint, amely vajúdás során a méhösszehúzódások csillapodását vagy akár leállását is eredményezheti [9]. A környezet streszszorai így hát le tudják állítani a vajúdás természetes folyamatát.

\section{Célkitüzés}

Célul tûztük ki, hogy a szakirodalom alapján vázolt szülési stressz alakulásával összefüggésbe hozható faktorokat saját mintán megvizsgáljuk. Három, szülés közben 
befolyásoló faktort kívántunk vizsgálni: a fizikai környezet biztonságának érzetét, a szüléskísérők jelenléte által kialakuló biztonságérzetet és a mesterséges oxitocinadagolást mint külső beavatkozást. Ezeket azután összevetjük a vajúdás és szülés során észlelt stressz szintjével. Feltételezésünk szerint ugyanis a megfelelő fizikai és társas szülési környezet biztosításával és csak a minimálisan szükséges közbeavatkozással támogathatjuk legmegfelelőbben a nő szervezetében szülés közben lejátszódó természetes hormonális folyamatokat és az optimális szülési élményeket.

\section{Módszer}

Jelen vizsgálatunk egy tágabb, több egyéb, a szülés eseményével kapcsolatos körülményt feltárni szándékozó kutatás keretei között valósult meg. Mivel az adatgyứjtést R. M. önkitöltős kérdőív által, már megszült anyák körében öt budapesti kórház gyermekágyas osztályán szándékozta végezni, ezért kutatásához engedélyt kért a részt vevő kórházak főigazgatójától, illetve az Egészségügyi Tudományos Tanács Tudományos és Kutatásetikai Bizottságától (etikai engedély száma: 19789-3/2016/ EKU). A koordinálási feladatokban való segítségre a kórházak vezető szülésznői lettek felkérve. A kutatásban való részvétel kritériumai a 18 év feletti életkor, a 37. és 42. terhességi hetek közötti hüvelyi úton történő szülés, komplikációmentes várandósság, az egy (és nem több) magzattal való várandósság, a koponyavégú méhen belüli elhelyezkedés voltak. Az adatfelvétel 2016 tavaszán kezdődött és 2016 őszén fejeződött be. Jelen vizsgálatban 343 nő adatát elemeztük. A teljes kérdőív kitöltése a szülés körülményeitől függően 10-20 percet vett igénybe. Tudatában vagyunk annak, hogy gyakran megterhelö az anyáknak szülésük után egy kérdőív kitöltése, amikor újszülöttjüket próbálják ellátni, és az új anyaszerepet próbálgatják. Amennyiben valami közbejött, később is folytathatták annak kitöltését a szülést követő három napon belül, amíg el nem hagyták a kórházat. Úgy véljük, hogy így a szülés eseménye után nem sokkal felvett adataink talán pontosabb képet mutatnak, és kevésbé voltak az emlékezet esetleges torzító hatásának kitéve.

Ez alkalommal vizsgálatunkban központi szerepet kapott a szülőnők által vajúdás és szülés során észlelt stressz, amelynek mérése az Észlelt Stressz Skála (Perceived Stress Scale - PSS) négy tételből álló rövidített verziójának (PSS-4) vajúdás és szülés körülményeire való adaptált változatával történt. A PSS eredeti verziója a stressz objektív jellemzőin túlmenően annak egyéni megítélését, megélését igyekszik megragadni [10]. Az eredeti angol nyelvű, 14 tételból álló és a rövidített, 10, illetve négy tételből álló verziók megbízhatóságát és érvényességét nagyszámú mintán igazolták, és ezek igazolása Magyarországon is egy kisebb mintán megtörtént [11]. A PSS-4 magyar verziójának itemei közti konzisztencia magas, azaz belső megbízhatósága igen jó (Cronbach-alfa 0,79$)$, és megállapítást nyert, hogy az eredeti
14 itemből álló teljes skála és annak rövidített, a kutatásunkban is használt négy itemból álló változatai szoros korrelációban állnak egymással, a verziók közti korreláció $0,93(\mathrm{p}<0,001)$ volt [11].

Kutatásunk céljának megfelelően a PSS-4 eredeti kérdéseiben megfogalmazott, az elmúlt hónapra vonatkozó időtartam vizsgálatát a vajúdás és szülés hosszára rövidítettük. Ennek megfelelően az eredeti PSS-4 kérdőívben szereplő itemek - például „Az elmúlt hónap során milyen gyakran érezte úgy, hogy a dolgok az Ön kedve szerint alakulnak?” és „Az elmúlt hónap során milyen gyakran érezte úgy, hogy a nehézségek úgy felhalmozódtak, hogy már nem tud úrrá lenni rajtuk?" - helyett a kérdések így hangoztak saját módosított verziónkban: „A vajúdás és szülés során milyen gyakran érezte úgy, hogy a dolgok az Ön kedve szerint alakulnak?” és „A vajúdás és szülés során milyen gyakran érezte úgy, hogy a nehézségek úgy felhalmozódtak, hogy már nem tud úrrá lenni rajtuk?" A PSS-4 a vajúdás és szülés helyzetére adaptált verziónkban tehát az eredetivel megegyezően négy kérdés mérte fel a nók által megtapasztalt stresszt, a fent példaként idézett két kérdésen túl még két további kérdés képezi a PSS-4 teljes itemlistáját. Az elemzés során a fordított tételeket megfordítottuk. A nők válaszaikat egy 0-tól 4-ig terjedő ötfokú Likert-skálán jelölhették, ahol a „0" a „soha” válasznak és a „4” a „nagyon gyakran” válasznak felelt meg. A skála egyes kérdéseinek terjedelme 0-4 volt, ahol a „0" és „1,5” közötti értékek számítanak alacsonynak, az „1,5” és „2" közöttiek átlagosnak, az e feletti értékeket magas stresszválaszként tekinthetjük az adott kérdésre vonatkozóan $[10,12]$. A PSS-4 összesített pontszámainak terjedelme 0 és 16 között változik, amelyek esetében az átlagos stressz-szint az ,5" és „7" közti értékeknek felel meg, az ez alatti értékeket alacsony, az e feletti értékeket magas stressz-szintként kezelhetjük [11, 12]. Cohen, az Észlelt Stressz Skálák kifejlesztője és szakmai felelőse a skála által rákérdezett időtartomány rövidítésével kapcsolatban - ahogy azt mi is tettük, hogy az egy hónapos időintervallumot a vajúdás és szülés hosszára rövidítettük - megjegyzi: azt akár egy napra is le lehet rövidíteni, nem jelent változást a skála pszichometriai jellemzőire nézve. Majd fontosnak tartja kiemelni, hogy mivel a PSS nem egy diagnosztikus skála, ezért nincsenek általánosan elfogadott alacsony, átlagos és magas értékek sem, hanem azok értékei mintánk függvényében változhatnak [12, 13].

Ezenkívül a saját fejlesztésű Szülési Intimitás és Privát Szféra Skála (Childbirth Intimacy and Privacy Scale CIPS) két iteme segítségével rákérdeztünk [7], hogy a szülőnő mennyire érezte magát a szülőszobán biztonságban, illetve hogy az ott tartózkodó emberek milyen mértékben árasztottak nyugalmat és biztonságot. A kismamák mindkét esetben egy ötfokú Likert-skála segítségével jelölhették válaszaikat, ahol „0” az „egyáltalán nem” választ, a „4” a „teljes mértékben” választ jelentette. A skála terjedelme mindkét kérdés esetében 0 és 4 között változott, ahol a „0"-hoz közelebbi értékek mel- 
lett alacsony, a „4"-hez közelebbi értékek mellett nagyobb mértékű biztonságot éltek meg a szülőnők a fizikai vagy a társas környezetre vonatkozóan. Utolsó, elemzésbe bevont kérdésünk arra vonatkozott, hogy a szülőnő kapott-e a vajúdása, illetve szülése során mesterséges oxitocint fájáserősítőként, és azt milyen hatásúnak érezte.

Ezek után a szociális környezet támogató jellegét próbáltuk tovább elemezni, és külön-külön rávilágítani, hogy a hivatásos (szülészorvos, szülésznő) és nem hivatásos (nő élettársa, más családtag) szüléskísérők közül vizsgálatunkban kik, milyen arányban voltak jelen a szüléseknél, és a szülőnők számára milyen mértékben mutatkozott jelenlétük támogatónak. A nők válaszaikat egy ötfokú Likert-skála mentén jelölhették, ahol „0” azt jelölte, hogy egyáltalán nem érezték támogatónak, a „4" azt, hogy teljesen támogatónak érezték az adott szüléskísérő jelenlétét.

A statisztikai elemzéseket SPSS programmal készítettük. Korrelációelemzést végeztünk az Észlelt Stressz Skála itemek, a fizikai és szociális biztonság, oxitocinbeavatkozás kapcsolatának megállapítására. Független kétmintás t-próbával vizsgáltuk a PSS-átlagokat a fizikai és szociális biztonság válaszok átlag szerinti cut-off pont mentén szétválasztott csoportokban. Továbbá azt is megvizsgáltuk, hogy a fizikai biztonság és szociális biztonság kérdések megítélésében volt-e jelentősége annak, hogy kaptak-e oxitocint a kismamák vagy sem, ennek vizsgálatára szintén kétmintás t-próbát használtunk. Utolsó lépésben az oxitocin és a stressz kapcsolatát kíséreltük meg feltárni. Az összesített stresszpontszám alapján átlag szerinti cut-off pont segítségével két csoportot képeztünk, majd $\chi^{2}$-próbával vizsgáltuk, hogy szignifikáns eltérés tapasztalható-e a létrehozott csoportokban.

\section{Eredmények}

Jelen kutatásunkban az észlelt stressz mértéke, a szülőszoba biztonsága, a szüléskísérők miatt érzett biztonság és az oxitocin szerinti összefüggések vizsgálatát tûztük ki célul. A PSS-4 skála megbízhatósági mutatója 0,791 volt a jelenlegi mintán, tehát a PSS magyar validáló vizsgálatában kapott értékkel tulajdonképpen azonosnak (Cronbach-alfa 0,79 ) foghatjuk fel, és a mérőeszközt megbízhatónak tekintjük. Az észlelt stressz mértéke inkább alacsony értékeket mutatott a mintában (1,16 és 1,61 átlagok között). A kismamák szüléskor alkalmanként szembesültek azzal, hogy a nehézségek felhalmozódásán képtelenek úrrá lenni $(M=1,61)$ vagy a fontos dolgokat képtelenek kézben tartani $(M=1,58)$; illetve ritkábban azzal, hogy a dolgok nem a kedvük szerint alakultak $(\mathrm{M}=1,49)$ és nem képesek megoldani a felmerülő problémákat $(\mathrm{M}=1,16)$ (1. táblázat). A teljes PSS-4 skála átlaga 5,83 (szórás $=3,3$ ) volt, vagyis átlagosnak mondható összesített stresszértékeket kaptunk.

A fizikai és szociális biztonságot felmérő kérdéseket tartalmazó teljes CIPS-skála megbízhatósági mutatója
1. táblázat $\mid$ Az Észlelt Stressz Skála itemek, fizikai és szociális biztonság leíró statisztikája

\begin{tabular}{lll}
\hline & Átlag (szórás) & Egyetértés mértéke \\
\hline PSS1 & $1,58(1,1)$ & $17,8 \%$ \\
PSS2 & $1,16(0,9)$ & $5,9 \%$ \\
PSS3 & $1,49(1,1)$ & $14,6 \%$ \\
PSS4 & $1,61(1,2)$ & $20,1 \%$ \\
Fizikai biztonság & $3,52(0,8)$ & $87,1 \%$ \\
Szociális biztonság & $3,70(0,7)$ & $91,8 \%$ \\
\hline
\end{tabular}

Megjegyzés: PSS1-4: Perceived Stress Scale, azaz az Észlelt Stressz Skála itemei 1-től 4-ig. Az egyetértés mértéke a nagyon és elég gyakran; valamint a teljesen és nagyon jellemző kategóriák összeillesztésével történt.

0,715-es értéket mutatott jelen mintán, amely a megbízhatósági küszöbérték feletti, tehát a mérőeszköz megbízhatónak mondható. A megkérdezettek túlnyomó többsége, azaz 87,1\% biztonságban érezte magát a szülőszoba fizikai környezetében, és 91,8\% értékelte úgy, hogy a szüléskísérők társaságában biztonságban érzi magát, vagyis szociális tekintetben biztonságban volt. Míg természetesen a szülészorvosok és szülésznők jelenléte általánosan jellemző volt a szüléseknél, az apa a nők 85,7\%-ánál, női rokon - aki egy-két eset kivételével a saját édesanya volt - a nók 7,9\%-ánál nyújtott támogatást. A hivatásos és nem hivatásos szüléskísérők anya által érzett támogatását mélyebben feltárva azt kaptuk, hogy a szülőnőknek a leghatékonyabb érzelmi támaszt az apák $(95,6 \%)$, majd a női rokonok nyújtották $(89,3 \%)$. A szülésznők jelenlétét a nők 84,6\%-ban, a szülészorvosokét 72,4\%-ban érezték teljes mértékben támogatónak ( 1 . ábra). A mesterséges oxitocin alkalmazása a minta felénél volt jellemző: 50,9\% számolt be arról, hogy esetében alkalmazták, és azon belül 83,8\% jellemzően kedvezőnek ítélte annak hatását.

Az észlelt stressz, a fizikai és szociális biztonságérzetre vonatkozó tételek változói között a korrelációelemzés

\section{Szüléskísérők támogatása}

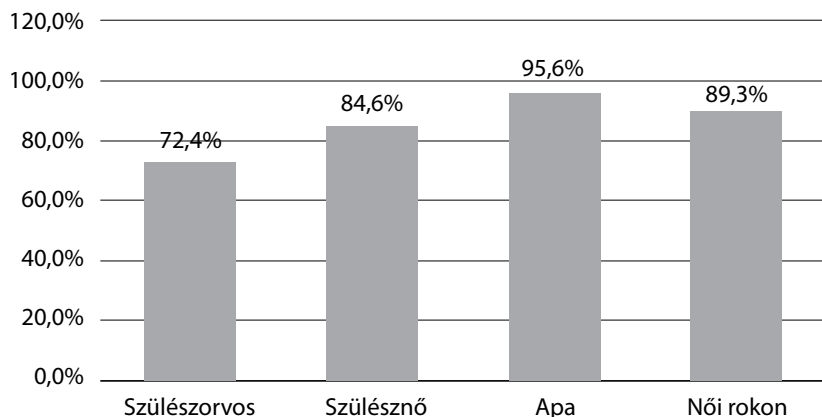

\begin{tabular}{l|l} 
1. ábra & A hivatásos és nem hivatásos szüléskísérók támogatása
\end{tabular} Megjegyzés: Az ábra a teljes mértékű támogatást jelöli százalé kos arányban 
2. táblázat |Az Észlelt Stressz Skála itemek, fizikai és szociális biztonság, oxitocinbeavatkozás korrelációs mátrixa

\begin{tabular}{|c|c|c|c|c|c|c|c|}
\hline & PSS1 & PSS2 & PSS3 & PSS4 & Fizikai biztonság & Szociális biztonság & Oxitocin $^{a}$ \\
\hline PSS1 & - & 0,478 ** & $0,378 * *$ & 0,623 ** & $-0,174$ ** & $-0,114^{*}$ & 0,90 \\
\hline PSS2 & & - & 0,542 ** & 0,508 ** & $-0,315^{* *}$ & $-0,225^{* *}$ & $0,126^{*}$ \\
\hline PSS3 & & & - & 0,457 ** & $-0,415^{* *}$ & $-0,297^{* *}$ & $0,126^{*}$ \\
\hline PSS4 & & & & - & $-0,212$ ** & $-0,168^{* *}$ & $0,123^{*}$ \\
\hline PSS-4 totál & & & & & $-0,348^{* *}$ & $-0,240^{* *}$ & $0,147^{*}$ \\
\hline Fizikai biztonság & & & & & - & 0,541 ** & $-0,222$ ** \\
\hline Szociális biztonság & & & & & & - & $-0,126^{* *}$ \\
\hline
\end{tabular}

Megjegyzés: PSS1-4: Perceived Stress Scale, azaz az Észlelt Stressz Skála itemei 1-től 4-ig. PSS-4 totál: Észlelt Stressz Skála összesített értéke. Spearman-féle Rho-értékek feltüntetve

${ }^{\mathrm{a}}$ Pearson-korreláció; ${ }^{*} \mathrm{p}<0,05,{ }^{*} \mathrm{p}<0,001$

3. táblázat | Észlelt Stressz Skála itemek átlagainak összevetése

\begin{tabular}{lllll}
\hline & $\begin{array}{l}\text { Fizikai biztonság } \\
\text { átlag alatti }\end{array}$ & $\begin{array}{l}\text { Fizikai } \\
\text { biztonság átlag } \\
\text { feletti }\end{array}$ & $\begin{array}{l}\text { Szociális } \\
\text { biztonság } \\
\text { átlag alatti }\end{array}$ & $\begin{array}{l}\text { Szociális } \\
\text { biztonság } \\
\text { átlag feletti }\end{array}$ \\
\hline PSS1 & $1,83(1,1)^{* *}$ & $1,46(1,0)$ & $1,81(1,1)^{*}$ & $1,52(1,0)$ \\
PSS2 & $1,55(0,9)^{* *}$ & $0,97(0,8)$ & $1,51(0,9)^{* *}$ & $1,06(0,8)$ \\
PSS3 & $2,12(1,0)^{* *}$ & $1,19(1,0)$ & $2,07(1,0)^{* *}$ & $1,33(1,0)$ \\
PSS4 & $1,93(1,2)^{* *}$ & $1,46(1,1)$ & $1,99(1,2)^{* *}$ & $1,51(1,1)$ \\
PSS-4 & $7,43(3,3)^{* *}$ & $5,08(3,0)$ & $7,38(3,3)^{* *}$ & $5,42(3,1)$ \\
totál & & & & \\
\hline
\end{tabular}

Megjegyzés: PSS1-4: Perceived Stress Scale, azaz az Észlelt Stressz Skála itemei 1-től 4-ig. PSS-4 totál: Észlelt Stressz Skála összesített értéke. ${ }^{*} \mathrm{p}<0,05,{ }^{* *} \mathrm{p}<0,001$.

4. táblázat | Fizikai és szociális biztonság átlagai oxitocinbeavatkozás szerint

\begin{tabular}{lccc}
\hline & $\begin{array}{c}\text { Nem kapott } \\
\text { oxitocint }\end{array}$ & $\begin{array}{c}\text { Kapott } \\
\text { oxitocint }\end{array}$ & t-érték \\
\hline Fizikai biztonság** & $3,7(0,6)$ & $3,4(0,9)$ & 4,2 \\
Szociális biztonság* & $3,8(0,5)$ & $3,6(0,7)$ & 2,3 \\
\hline
\end{tabular}

Megjegyzés: ${ }^{*} \mathrm{p}<0,05,{ }^{*} \mathrm{p}<0,001$

szoros összefüggéseket mutatott (2. táblázat). Az észlelt stressz skála tételei, valamint a fizikai, illetve társas biztonságérzet tételek egymással - vagyis skálán belül - szoros pozitív összefüggésben állnak (fizikai biztonság és társas biztonság $\mathrm{r}=0,541, \mathrm{p}<0,001)$. Emellett az észlelt stressz és a fizikai, illetve szociális biztonságra vonatkozó tételek szoros negatív összefüggésekre engednek következtetni. Tehát minél alacsonyabb a szülőszoba biztonságának és a szüléskísérók nyújtotta biztonság érzékelése, annál magasabb az észlelt stressz. Az oxitocin kapcsán pedig megfigyelhető, hogy akik kaptak oxitocint, azok magasabb stressz-szintet és alacsonyabb biztonságérzetet jelöltek mind a fizikai, mind a társas környezetre vonatkozóan.
A fizikai és szociális biztonság válaszok átlagértékei szerint szétválasztott csoportok PSS-értékei között szignifikáns különbségeket tapasztaltunk. A 3. táblázat mutatja az átlag alatti és feletti csoportok PSS-átlagértékeit. Megállapíthatjuk, hogy a fizikai és szociális biztonság kérdéseiben átlag alatti értékeket jelzők csoportja szignifikánsan magasabb átlagértékeket ért el a PSS-skálán.

Ezek után azt fedtük fel, hogy a fizikai és szociális környezet biztonságérzet ítéleteiben volt-e jelentősége annak, hogy kaptak-e oxitocint a kismamák vagy sem (4. táblázat). Akik nem kaptak oxitocint, azok szignifikánsan magasabb értékeket jelöltek a fizikai biztonság $(\mathrm{t}=4,2, \mathrm{p}<0,01)$ és szociális biztonság kérdéseknél $(\mathrm{t}=2,3, \mathrm{p}<0,05)$. A fizikai biztonság átlaga 3,7 (szórás = $0,6)$ azoknál a kismamáknál, akik nem kaptak oxitocint és 3,4 (szórás $=0,9$ ), akik kaptak; míg a szociális biztonság átlaga 3,8 (szórás $=0,5$ ) azoknál a kismamáknál, akik nem kaptak oxitocint és 3,6 (szórás $=0,7$ ), akik kaptak.

Utolsó lépésként az oxitocin és a stressz kapcsolatát tártuk fel. A korrelációelemzés már megmutatta, hogy akik kaptak oxitocint, azok magasabb stressz-szintet és alacsonyabb biztonságérzetet jelöltek meg a kérdőívben. Az összesített stresszpontszám alapján kettéosztott csoportok közül az átlag alatti csoportba a minta $46,5 \%$-a, az átlag felettibe pedig 53,5\%-a került. A két csoport közti szignifikáns eltérések $\chi^{2}$-próbával történő vizsgálata szerint a két csoportban $\left(\chi^{2}=3,7, p=0,054\right)$ tendenciaszerú eltérés tapasztalható. Vagyis, akik nem kaptak oxitocint, 51,8\%-ban számoltak be átlag alatti észlelt stresszről, míg ez az arány $41,4 \%$ volt azok körében, akik kaptak oxitocint. Emellett akik nem kaptak oxitocint, 48,2\%ban számoltak be átlag feletti észlelt stresszról, míg ez az arány $58,6 \%$ volt azok körében, akik kaptak oxitocint.

\section{Megbeszélés és modell}

A nemzetközi irodalom áttekintése alapján megállapíthatjuk, hogy a különféle beavatkozások jelentős stresszt jelentenek az anya és a magzat számára egyaránt [14, 15]. Jelen vizsgálatunkban a külső beavatkozásként sze- 
replő mesterséges oxitocin általi szülésgyorsítás szintén a kismamák magasabb stressz-szintjével járt együtt. A természetes úton szült kismamák nagyjából fele mesterséges oxitocint kapott vajúdás és szülés során. Érdemes azon elgondolkodni, hogy mi állhat annak hátterében, hogy ilyen magas volt ez az arány, és valóban elhisszük-e azt, hogy a nók fele csak szintetikus oxitocin segítségével képes szülni. Feltételezhetjük, hogy a kórházi alkalmazottak már szinte rutinszerúen alkalmazzák a mesterséges oxitocint, illetve nem hagynak elég időt a kismamának, hogy természetesen, a maga ütemében történjen szülése. Valószínűsíthető, hogy nincsenek egységes elvek arra vonatkozóan, hogy milyen hosszú szünet után beszélhetünk dystociáról, vagyis a vajúdási folyamat lelassulásáról, leállásáról, és ez a szüléskísérők egyéni megítélésén múlik. Svéd szülésznők beszámolóiból egyértelműen fény derül arra, hogy a szülésznők egyfajta belső konfliktust élnek át munka közben [16]. Egyrészről megfelelően szeretnék támogatni a szülőnőt, másrészről kompetens szakszemélyzetként szeretnének mutatkozni kollégáik előtt, harmadrészt a szülészeti osztály munkahelyi kultúrájával összhangban szeretnének dolgozni. Ez gyakran oda vezet, hogy mindig egy lépéssel a folyamatok előtt próbálnak járni, és meg akarják előzni a méhösszehúzódások folyamatának lelassulását, leállását. Ezért a szülési folyamatot gyorsítják, és mivel Svédországban és sok egyéb országban ez kompetenciájukhoz hozzátartozik - az indokoltnál hamarabb nyúlnak a mesterséges oxitocin alkalmazásához. Viszont abban általánosan egyetértenek, hogy a szülési folyamat gyorsítására a mesterséges oxitocin adása mellett vagy helyett egyéb módokat is érdemes alkalmazni, mint amilyen a szülőnővel való együttlét, nyugodt légkör megteremtése és az anyák testhelyzet-változtatásra való ösztönzése.

Ezenkívül fel kell hívni a figyelmet arra az ellentmondásra, hogy bár tudatosan a nők $83,8 \%$ arányban azt a választ adták, hogy inkább kedvező hatásúnak ítélték a mesterséges oxitocin alkalmazását, az oxitocin adása esetükben mégis magasabb stressz-szintekkel járt együtt. Úgy véljük, hogy tudatosan elfogadták azt, hogy esetükben alkalmazni kellett a szintetikus oxitocint, és nem kérdőjelezték meg alkalmazásának indokoltságát. Ez viszont minden bizonnyal hozzájárult ahhoz, hogy kevésbé érezték magukat aktív ágensnek [17], és kevésbé érezték, hogy kezükben tartják, azaz kontrollálják az eseményeket szülésük során. A stresszhelyzetben az alacsony kontroll érzete magasabb stressz-szintekkel jár együtt, amely összefüggés szülés közben is megállja helyét. Christiaens és Bracke több, anyák szülési elégedettségével kapcsolatos faktort mérve azt találták, hogy az anya azon érzete, hogy kontrollálja az eseményeket, magas fokú énhatékonyságot él át és előzetes várakozásai teljesülnek, alapvetően befolyásolják elégedettségét [18].

A stressz és az oxitocin kapcsolatát elemezve számot kell adnunk összefüggésük fiziológiai megalapozottságáról is. Az endogén oxitocin felszabadulása hozzájárul a stressz csökkentéséhez, ami alapvető a szülési fájdalom- mal való megküzdés során [2]. A szintetikus oxitocin adagolása viszont csökkenti vagy akár le is állítja a természetes oxitocin termelődését [14], vagyis alkalmazásával egy fontos fiziológiai alapokon nyugvó stresszkezelési mechanizmustól fosztjuk meg a szülőnőt. Feltételezhetjük ezek alapján, hogy a vizsgálatunkban szerepelt nők esetében ez hasonlóan történt, vagyis a mesterséges oxitocin hatására lecsökkent az endogén oxitocintermelödés a nők testében, így nem tudott segíteni stressz-szintjük szinten tartásában, miáltal magasabb fokú stresszt éltek át, mint akik nem kaptak mesterséges oxitocint. A természetes oxitocin hiányában a kétféle stresszkezelési mechanizmus közül a „nyugalom és összetartozás” rendszer helyett a „harcolj vagy menekülj” rendszer aktiválódott esetükben [1], stressz-szintjük megemelkedett, amely a méhösszehúzódások további lelassulását, leállását vonhatja aztán maga után [9]. Ekképpen tehát egy negatív öngerjesztő kör veheti kezdetét, ami megnöveli a helyi érzéstelenítés, az instrumentális szülésbefejezés, a császármetszés, és különféle anyai és újszülöttmorbiditások valószínúségét [14]. A beavatkozások alkalmazása, korábbi kutatások tanúsága szerint, ezentúl pszichés szinten is kifejti hatását: szorosan összefügg az anyák szülés utáni alacsonyabb elégedettségével, csökkent önértékelésével, ezek következtében a szoptatás kialakulásának sikertelenségével, illetve esetükben a különböző pszichés zavarok kialakulásának kockázata is megnő $[19,20]$.

Kutatásunkban azt is tapasztaltuk, hogy a fizikai környezet biztonságának érzete erős összefüggésben áll a szülés során észlelt stresszel. Továbbá, akik nem érezték magukat biztonságban a szülőszoba fizikai környezetében, azok magasabb stresszt éltek át. Faby és Parratt rámutatnak, hogy minél inkább kényelmes, otthonos és ismerôs a nő számára a szülés helyszíne, annál nagyobb biztonságban érzi ott magát, amely növeli magabiztosságát is [21]. Megállapítják, hogy a biztonságosnak érzett terek nyugalmat árasztanak, amik kedveznek a befelé fordulásnak és elmélyedésnek. A vajúdás során jellemző, hogy a nook a méhösszehúzódások fájdalmával való szembenézéskor szükségét érzik, hogy magukra összpontosítsanak, és kizárják a külvilág zavaró ingereit. Tehát a biztonságosnak érzett terek lehetővé teszik ezt a befelé fordulást, és adatainkból is úgy tû́nik, ennek köszönhetően csökken az észlelt stressz is. Ellentétes esetben túl kitettnek, sérülékenynek érzik magukat egy számukra barátságtalan, rideg térben, és a stressz is megemelkedik [8].

Alehagen és mtsai a stresszhormonok méréseiből arra következtetnek, hogy a szülés során a nagy fizikai megterhelés ellenére a mentális stressz mégis dominál a fizikai stressz felett [22]. Az anyák tehát nem is magát a fájdalmat élik meg nehezen, hanem az azzal való mentális megküzdés teszi óket inkább próbára. Ez arra hívja fel a figyelmet, hogy annál nagyobb szükség van az anyák megküzdését segítő emocionális támogatásra, odafigyelő gondoskodásra. Eredményeink szintén alátámasztják ezt 


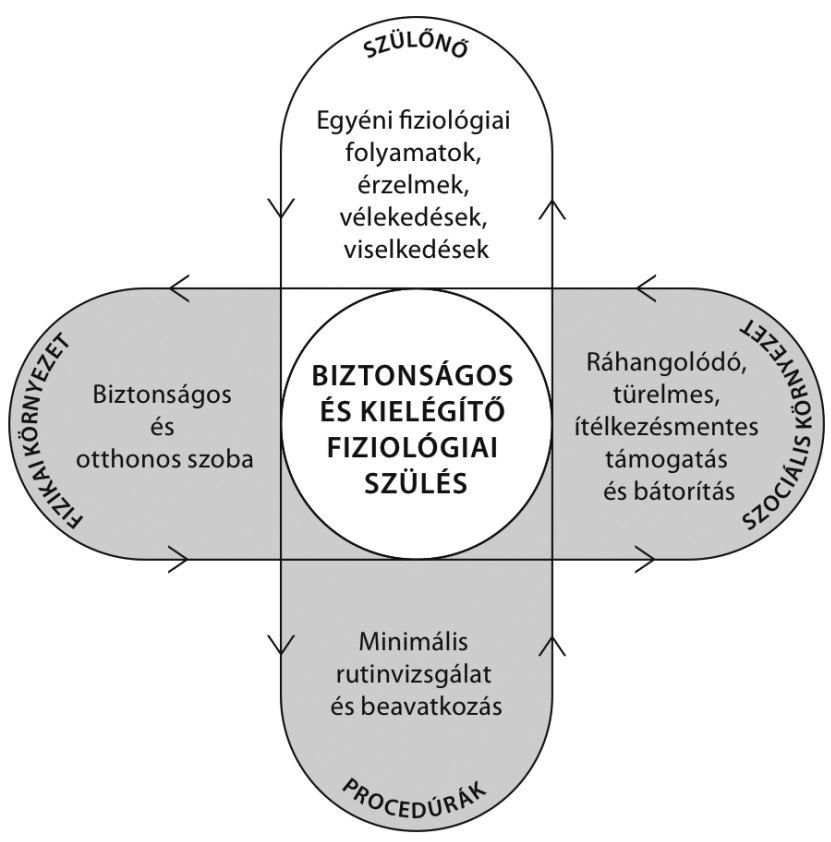

2. ábra

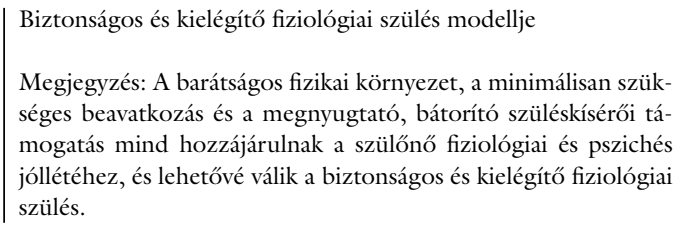

a nézetet, mivel mintánkban a szociális biztonság érzete, azaz a szüléskísérôk által biztosított nyugodt légkör szoros összefüggést mutatott az alacsonyabb stressz-szintekkel. Továbbá azt is tapasztaltuk, hogy mind a hivatásos, mind a nem hivatásos személyek támogatása alapvetően fontos a nők számára a vajúdás és szülés stresszének kezelésében. Ez egybecseng a nemzetközi szakirodalom adataival, miszerint a nők stresszük jellemzésében általánosan hangot adnak annak, hogy vajúdás és szülés közben sérülékenynek és magára hagyottnak érzik magukat, amelyet leghatékonyabban a gondozást ellátó személy folyamatos jelenléte és pozitív támogatása old [23]. Hodnett és mtsai több mint 15000 nő adatát vizsgálva megállapították, hogy akik szülésénél folyamatosan jelen volt egy bátorító, támogató személy, azok nagyobb valószínúséggel szültek spontán hüvelyi úton, kevésbé igényeltek szülés közben fájdalomcsillapítást, és elégedettebbek voltak szülési élményeikkel [24].

Egy modell segítségével kívánjuk szemléltetni, ahogyan a kutatásunkban vizsgált faktorok, azaz a támogató fizikai és társas környezet, valamint a csak ténylegesen indokolt rutinszerú beavatkozások végrehajtása az egyéni fiziológiai és pszichés folyamatokkal kölcsönhatásban egy olyan nyugodt légkört képesek teremteni, amelyben a nők a szülés stresszével - támogató és gondoskodó környezetben - hatékonyan képesek megküzdeni, és egy biztonságos és kielégítő szülésélményben lehet részük (2. ábra).
Anyagi támogatás: A közlemény megírása, illetve a kapcsolódó kutatás anyagi támogatásban nem részesült.

Szerzői munkamegosztás: R. M.: A közlemény alapötlete, szakirodalom-kutatás, a vizsgálat levezetése, a kézirat megírása, a modell kidolgozása. M. J.: A közlemény többszöri átnézése, korrekciós javaslatok. A cikk végleges változatát mindkét szerző elolvasta és jóváhagyta.

Érdekeltségek: A szerzőknek nincsenek érdekeltségeik. A közlemény Rados Melinda PhD-kutatásához kapcsolódik, amelynek témavezetője Dr. Mészáros Judit.

\section{Köszönetnyilvánítás}

Köszönet illeti az adatgyújtés során a koordinálási feladatokban részt vállaló vezető ápolókat, a sok segítséget nyújtó szülésznőket és a kismamákat, akik drága idejükkel, válaszaikkal támogatták a kutatást.

\section{Irodalom}

[1] Uvnäs Moberg K. The oxytocin factor: tapping the hormone of calm, love, and healing. Da Capo Press, New York, 2003.

[2] Dixon L, Skinner JP, Foureur M. The emotional and hormonal pathways of labour and birth: integrating mind, body and behavior. New Zealand College of Midwives J. 2013; 48: 15-23.

[3] Lazarus RS. From psychological stress to the emotions: a history of changing outlooks. Annu Rev Psychol. 1993; 44: 1-21.

[4] Selye J. Stress without distress. [Stressz distressz nélkül.] Akadémiai Kiadó, Budapest, 1976. [Hungarian]

[5] Folkman S, Lazarus RS. If it changes it must be a process: study of emotion and coping during three stages of a college examination. J Pers Soc Psychol. 1985; 48: 150-170.

[6] Wijma K, Wijma B, Zar M. Psychometric aspects of the W-DEQ: A new questionnaire for the measurement of fear of childbirth. J Psychosom Obstet Gynaecol. 1998; 19: 84-97.

[7] Rados M, Kovács E, Mészáros J. Intimacy and privacy during childbirth. A pilot-study testing a new self-developed questionnaire: the Childbirth Intimacy and Privacy Scale (CIPS). New Medicine 2015; 19: 16-24.

[8] Hammond A, Foureur M, Homer CSE, et al. Space, place and the midwife: Exploring the relationship between the birth environment, neurobiology and midwifery practice. Women Birth 2013; 26: 277-281.

[9] Stenglin M, Foureur M. Designing out the fear cascade to increase the likelihood of normal birth. Midwifery 2013; 29: 819825.

[10] Cohen S, Williamson GM. Perceived stress in a probability sample of the United States. In: Spacapan S, Oskamp S. (eds.) The social psychology of health. Sage, Newbury Park, CA, 1988; pp. 31-67.

[11] Stauder A, Konkolÿ Thege B. Characteristics of the Hungarian version of the Perceived Stress Scale (PSS). [Az Észlelt Stressz Kérdőiv (PSS) magyar verziójának jellemzői.] Mentálhigiéné és Pszichoszomatika 2006; 7: 203-216. [Hungarian]

[12] Cohen S. Contrasting the hassles scale and the perceived stress scale: Who's really measuring appraised stress? Am Psychol. 1986; 41: 716-718.

[13] Cohen S. PSS: The Perceived Stress Scale. Frequently-asked questions. FAQs updated February 17, 2014. Available from: http://www.psy.cmu.edu/ scohen/PSSfaqs.doc [accessed: May $15,2017]$.

[14] Olza-Fernández I, Marín Gabriel MA, Gil-Sanchez A, et al. Neuroendocrinology of childbirth and mother-child attachment: 
The basis of an etiopathogenic model of perinatal neurobiological disorders. Front Neuroendocrinol. 2014; 35: 459-472.

[15] Lothian JA. Safe, healthy birth: what every pregnant woman needs to know. J Perinat Educ. 2009; 18: 48-54.

[16] Ekelin M, Svensson J, Evehammar S, et al. Sense and sensibility: Swedish midwives' ambiguity to the use of synthetic oxytocin for labour augmentation. Midwifery 2015; 31: e36-e42.

[17] Hodnett ED, Simmons-Tropea DA. The Labour Agentry Scale: psychometric properties of an instrument measuring control during childbirth. Res Nurs Health 1987; 10: 301-310.

[18] Christiaens W, Bracke P. Assessment of social psychological determinants of satisfaction with childbirth in a cross-national perspective. BMC Pregnancy Childbirth 2007; 7: 26.

[19] Zelkowitz P, Gold I, Feeley N, et al. Psychosocial stress moderates the relationships between oxytocin, perinatal depression, and maternal behavior. Horm Behav. 2014; 66: 351-360.

[20] Beck CT. Post-traumatic stress disorder due to childbirth: the aftermath. Nurs Res. 2004; 53: 216-224.
[21] Fahy K, Parratt J. Birth territory: a theory for midwifery practice. Women Birth 2006; 19: 45-50.

[22] Alehagen S, Wijma K, Lundberg U, et al. Catecholamine and cortisol reaction to childbirth. Int J Behav Med. 2001; 8: 50-65.

[23] Van der Gucht N, Lewis K. Women's experiences of coping with pain during childbirth: a critical review of qualitative research. Midwifery $2015 ; 31: 349-358$.

[24] Hodnett ED, Gates S, Hofmeyr GJ, et al. Continuous support for women during childbirth. Cochrane Database Syst Rev. 2007; 18: CD003766.
(Rados Melinda,

Budapest, Vas u. 17., 1088 e-mail: melinda.rados@gmail.com)

\section{TÉVESZMÉEK AZ ALTERNATIV GYÓGYÁSZATBAN?}

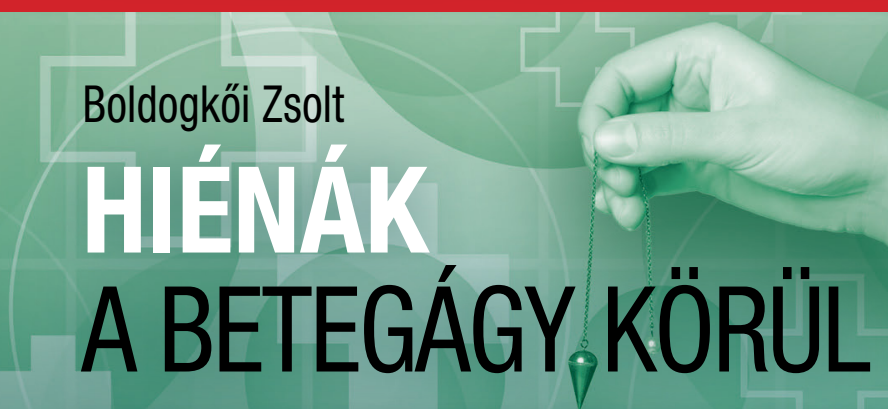

A szerző molekuláris biológusként elszántan küzd az áltudomány és a beteg ember kiszolgáltatott helyzetét kihasználó „kuruzslás” ellen. Könyvében a következỏ kérdéseket veti fel, állásfoglalása egyértelmü:

-Van-e tudományos alapja az íriszdiagnosztikának, homeopátiának, lúgositásnak, energiamezőknek?

- Miért csökken a tudományos gyógyítás presztízse, míg az alternatív gyógyítás népszerüsége egyre nő?

- Hogyan mérhető a terápia, a diéta hatása, miért hisznek a betegek csodaszerekben?

- Miért hajlandók sokan komoly összeget áldozni kétséges hatású terápiákra, szerekre, gyógyhatású készitményekre?

320 oldal, $3400 \mathrm{Ft} \bullet$ világraszóló tudás • www.akademiaikiado.hu
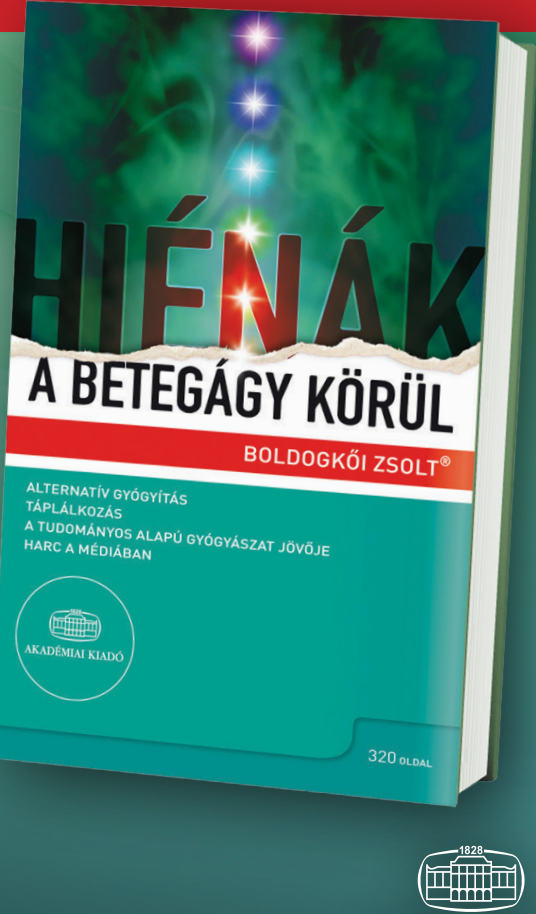

AKADÉMIAI KIADÓ 